\title{
Low-rise intensive residential development genesis and shaping the model
}

\author{
Wojciech Matys \\ Katedra Konstrukcji Budowlanych i Architektury, Wydziat Budownictwa \\ i Inżynierii Środowiska, Politechnika Białostocka
}

\begin{abstract}
The article focuses on exploring prototypic, historical examples of low - rise intensive residential developments. In terms of the form, such buildings are reminiscent of modern residential constructions in single family housing complexes, however, they are characterized by the presence of two flats in one residential segment. Such dwelling units have the size of a three-room flat as in multi-family housing but at the same time they are built on the basis of the law regulations reserved for single-family housing.
\end{abstract}

Key words: residential developments, low-rise, intensive, high-density housing development

\section{Introduction}

Currently on the real estate market we are observing numerous realizations of single-family housing characterized by the presence of two flats, mostly with three rooms, in one segment constituting a complex of compact development area - twin or terraced. In consequence, minimum four flats comprise one building. As a result, the density of population as well quantitative and quantitative parameters of the infrastructure supporting the investment increase (Fig. 1.).

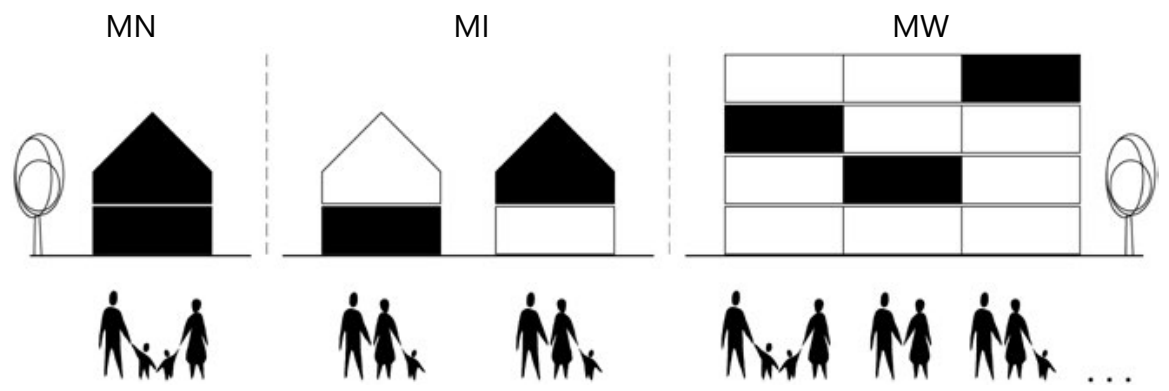

Fig. 1. Type of building schema: $M N$ - single-family housing, including single family compact housing (twin, terraced, group), MI - intensive development in single family housing, MW - multi-family housing; Source: author's graphic

In effect, we obtain low- rise intensive housing development. The term "low-rise" refers to a two-storey or three-storey building, including an adapted loft (attic). The term "intensive" is to describe the situation in which flats within one building or segment thereof are situated over and under or are adjoined.

\section{Materials and methods}

In search for the prototypes of modern low-rise intensive housing, historical examples of housing development in higher density areas which would meet the criteria of building height and number of units were analyzed. 
The examples were taken from publications on housing development, including social, patronage, and individual housing in the period from the 16 th century to the beginning of the 20 th century. The research was extended to Internet sources. The analysis refers to such projects for which finding proofs supporting the stated objectives can be found. The publication presents selected characteristic constructions to illustrate the three particular types of buildings described below.

\section{Results and discussion}

The development of low-rise intensive housing can be linked to:

- social housing - connected with Christian axiology and the imperative to provide shelter for the poor

- patronage housing - connected with the industrial revolution, which dates back to the end of the 18th century [Lamparska 2017], and with the emerging social working class-proletariat, whose influx and consequent demand for residential development resulted in the creation of new settlement structures - on-site workers' premises i.e. patronage housing [Lamparska 2017], located at emerging industrial plants, factories, mines and steelworks.

- manor farm complexes - erected on manor land estates, farms as a residence for court manors, workers, senior workers and technical employees

n private residential development - associated with small residential constructions

The research allowed to identify characteristic forms of low-rise intensive residential development, which helped to define mostr freqent solutions used in the construction and design of this type of residential development.

We can distinguish three most popular types of buildings (Fig. 2.)

1. over-and-under flat type buildings in a terraced development

2. four-family residential buildings divided into 4-dwelling units

3. back-to-back residential buildings (blind-backs) [http://snailinthecity..., access: 15.07.2017]

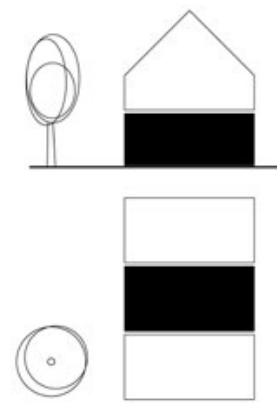

1)

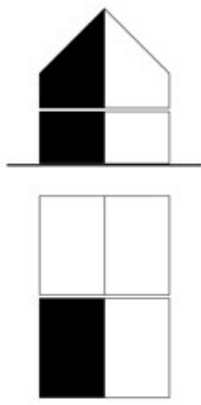

2)

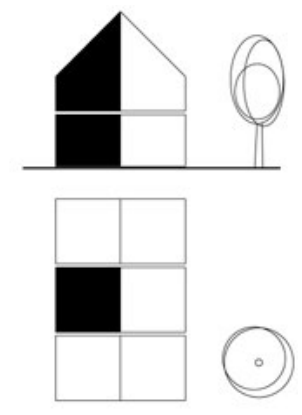

3)
Fig. 2. Type of buildings: 1) overand-under flat type buildings, 2) four-family residential buildings, 3) back-to-back residential buildings; Source: author's graphic

\section{Over-and-under flat type buildings in a terraced development}

In this type of development, there are two flats situated one on top of the other, within one building or segment, arranged in a row. The entrance to flat premises is resolved in two ways. In the first case, each entrance is independent, with an outside or an interior staircase leading to the upper flat. In the second case, the apartments are accessible from a common corridor, which also includes stairs to the upper storey.

The oldest example of a low-rise intensive housing development with such a type of a building model is a social housing estate Fuggerei in Augsburg [Zadworny 2013] intended for the impoverished Catholic bourgeois families, constituting 56 two-storey adjoining row houses. Each segment comprises of two over-andunder flats of approximately $60 \mathrm{~m}^{2}$ each, with 3 rooms, a kitchen, and a separate entrance (Fig. 3, Fig. 4). Each flat also had a small green yard or attic. The estate included a church, a school, a hospital and an infirmary and was surrounded by a wall. 


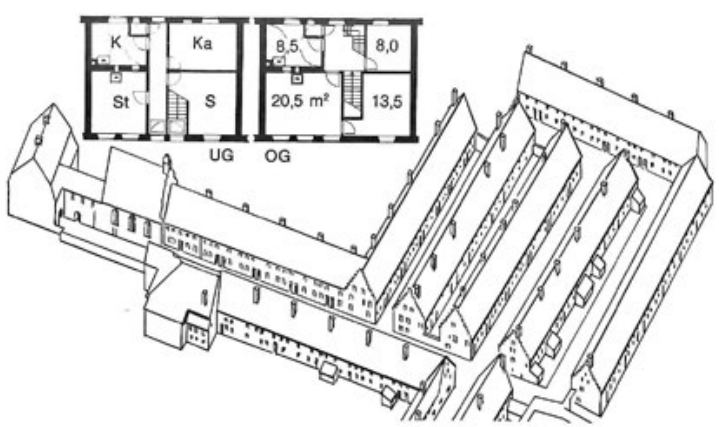

Fig. 3. Fuggerei, Ausburg; Source: Koch 1996, p. 417

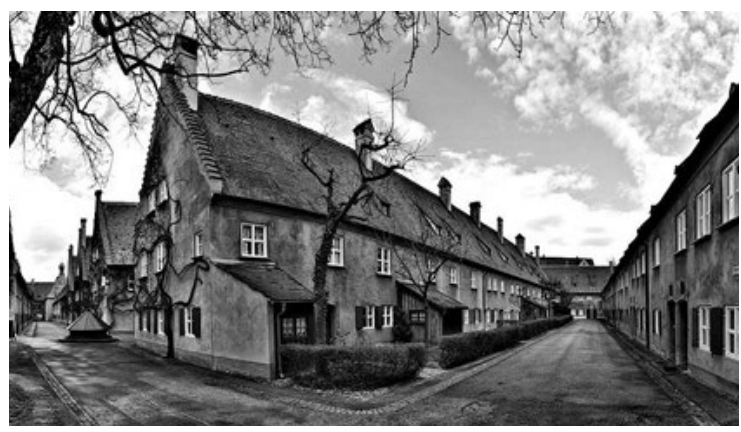

Fig. 4. Fuggerei, Ausburg; Source:http://www.fotocommunity. de..., access: 02.03.2016

A similar layout of the building can also be found in one of the first workers' housing estates, located in Saltaire, near Bradford, West Yorkshire, England, built by an industrialist Titus Salta in 1853. Built within the local textile manufacturing plants, the premises included dwellings for workers and executives, textile factory buildings, public buildings, schools, church, hospital and meeting room [Lamparska 2017] (Fig. 5).

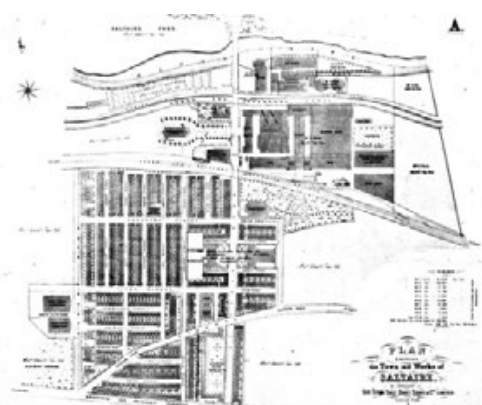

Fig. 5. Saltaire plan; Source: https://www.flickr.com/photos / bradfordlibraries..., access: 02.03.2016

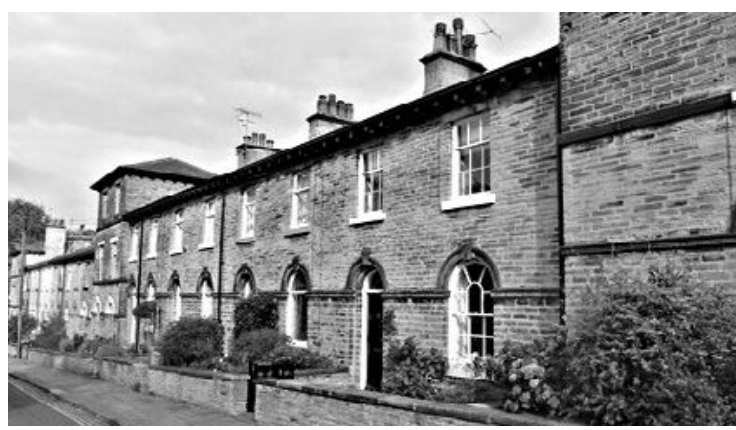

Fig. 6. Saltaire workers'dwellings; Source: https://greatacre. wordpress.com/2011/10/, access: 02.03.2016

The residential area included 850 residential units located in two-storey segments arranged in terraced layout. The apartments differed in function and comfort depending on the class of employees (Fig. 6). The simplest and smallest houses were located on the periphery of the estate, at a considerable distance from the main road. Nearer the center were larger, more ornamental buildings, which also had small backyard gardens [https://greatacre..., access: 02.03.2016]
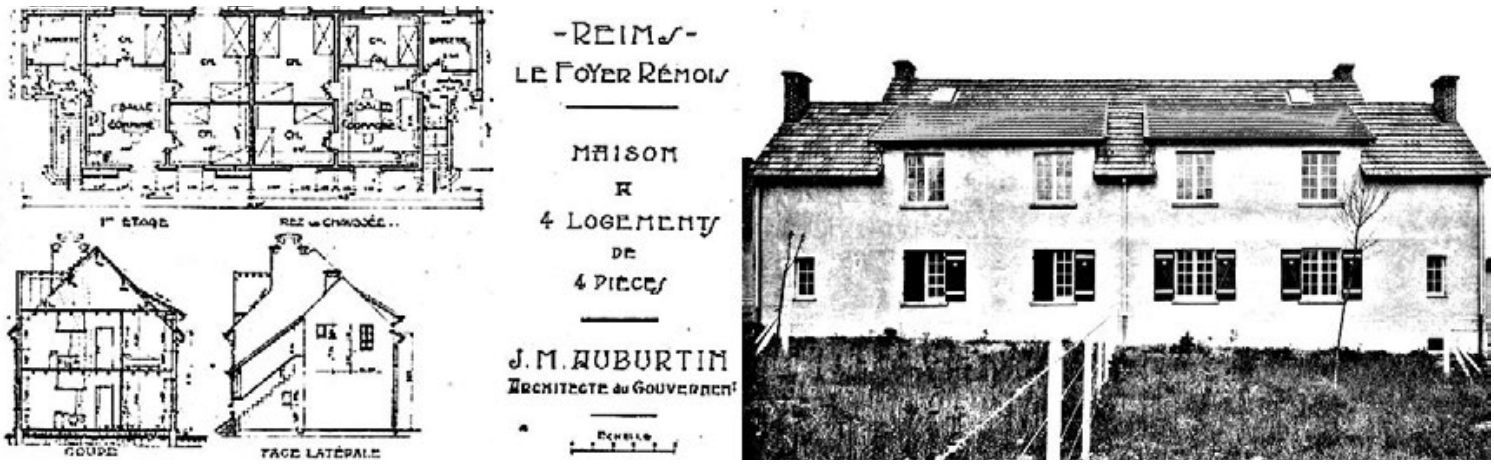

Fig. 7. A twin building with 4 flats, Chemin Vert; Source: http://www.cite-jardin-reims.culture.fr..., access: 20.07.2017 
Another example is the city of Chemin Vert, located in Reims, France. The settlement was built between 1919 and 1922. During that period, 617 flats were built in 14 different types of buildings [http://www.cite-jardin-reims. culture.fr/..., dated 20.07.2017]. One of them was an over-and-under flat type arrangement. The two-storey building consisting of four (two on each floor), over-and-under three-roomed units with a kitchen and a designated garden. The second floor flats were accessible from external stairs (Fig. 7.).

The intensive low-rise housing development in the over-and-under flat type arrangement was also used for the construction of social housing in Denmark e.g. in one of Denmark's oldest settlements, Brumleby, which was established by the Danish Medical Association between 1854 and 1872; today located in the Østerbro district of Copenhagen [https://en.wikipedia... access: 13.09.2017]. The designers were Michael Gottlieb Bindesbøll and Vilhelm Klein [https://web.archive..., access: 13.09.2017]. The over-and-under flat type residential units of about $25 \mathrm{~m}^{2}$ [https://en.wikipedia..., access: 13.09.2017] are available from a transitive corridor and are located in a two-storey building of a simple shape covered with a flat, double-pitched roof. The apartments include gardens on the ground floor; common green areas are located between the buildings (Fig. 8, Fig. 9).

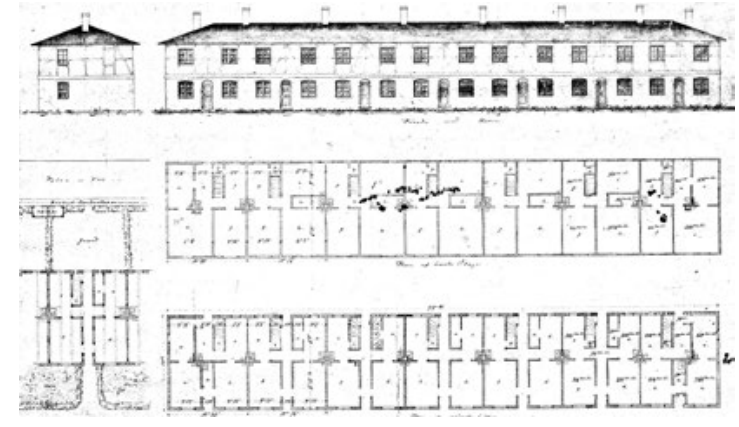

Fig. 8. Brumleby,Kopenhaga; Source: http://kunstbib.dk/ samlinger/arkitekturtegninger..., access: 13.09 .2017

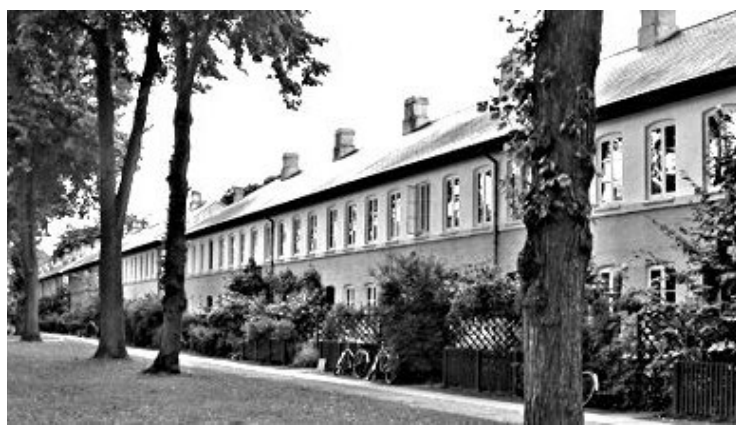

Fig. 9. Brumleby,Kopenhaga; Source: https://upload.wikimedia. org/wikipedia/commons/1/12/Brumleby..., access: 13.09.2017

In Copenhagen, one can find a family estate called the "Potato Rows" (Kartoffelrækkerne) erected by the Workers' Association, in the Østerbro district. Between 1873-1889, based on the design of an architect Frederik Christian Bøttger [https://da.wikipedia... , access: 14.4.2017] rows of simple, three-storey (including attic) English style buildings (Fig. 10.) were built along eleven municipal streets. In each of the house, erected in terraced layout, maximum three dwelling units were designed, including one in the attic, accessible from a common staircase (Fig. 11). The apartments had a common entrance and front and back gardens. A total of 480 apartments were built within the estate.

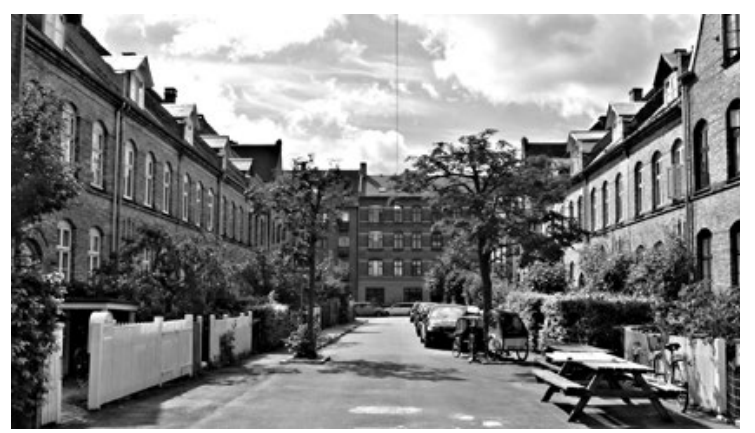

Fig. 10. Potato Rows,Kopenhaga; Source: http://1.bp.blogspot. com..., access: 14.09.2017

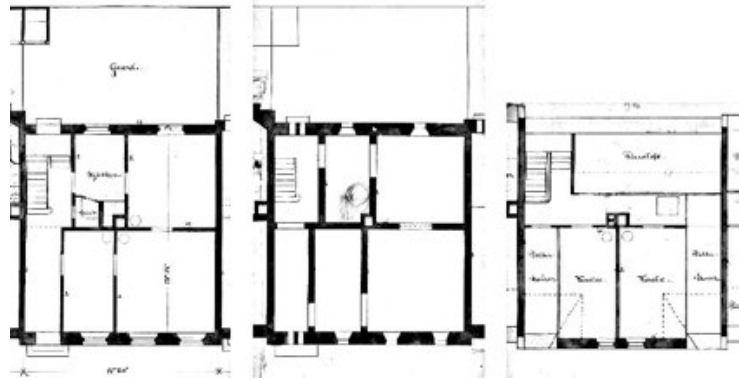

Fig. 11. Potato Rows,Kopenhaga; Source: http://kunstbib.dk/ samlinger/arkitekturtegninger..., access: 14.09.2017

Another example of the over-and-under flat type housing development is workers' housing estate at Hoek van Holland, Rotterdam, designed in 1924 by a modernist Jacobus Johannes Pieter Oud and built between 
1926-1927 [http://www.architectuurgids..., access: 10.10.2017]. A two-storey elongated-shape building, divided into two separate residential parts, which also included service units and a library (Fig. 12.). The residential area itself consisted of three-room flats on the ground floor and alternate two- and four-room units on the second floor (Fig. 13). Dwellers had separate front and back gardens.

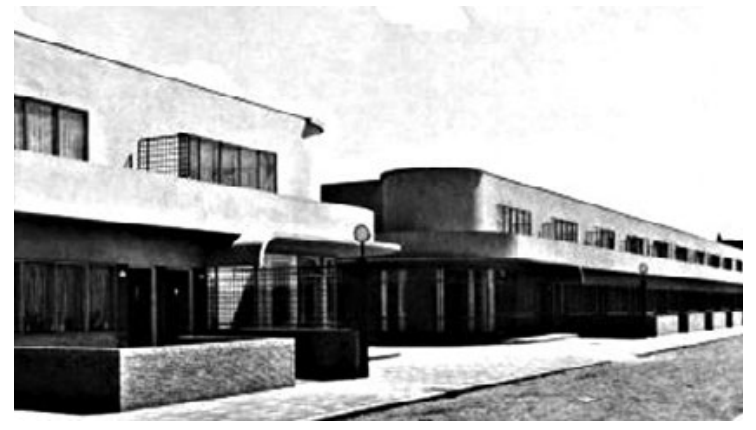

Fig. 12. Hoek van Holland, front elevation; Source: http:// davidhannafordmitchell.tumblr.com..., access: 10.10.2017
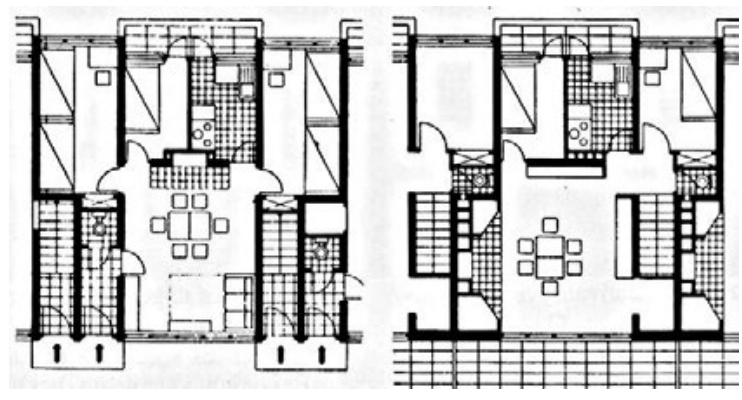

Fig. 13. Hoek van Holland, floor plans; Source: https://i.pinimg com/originals..., access: 10.10.2017

The type of building with over-and-under flat layout is also found in small housing projects. One example is the catalog issued by the National Capital Fund (Bank Gospodarstwa Krajowego) in 1934, which is a collection of projects selected in a competition for a conventional small house. Among others, there are projects of twin or terraced segments consisting of two over-and-under flats with a kitchen (Fig. 14) There are also situation diagrams, schemas for arrangements of segments, as well as arrangements of windows in middle and end units.
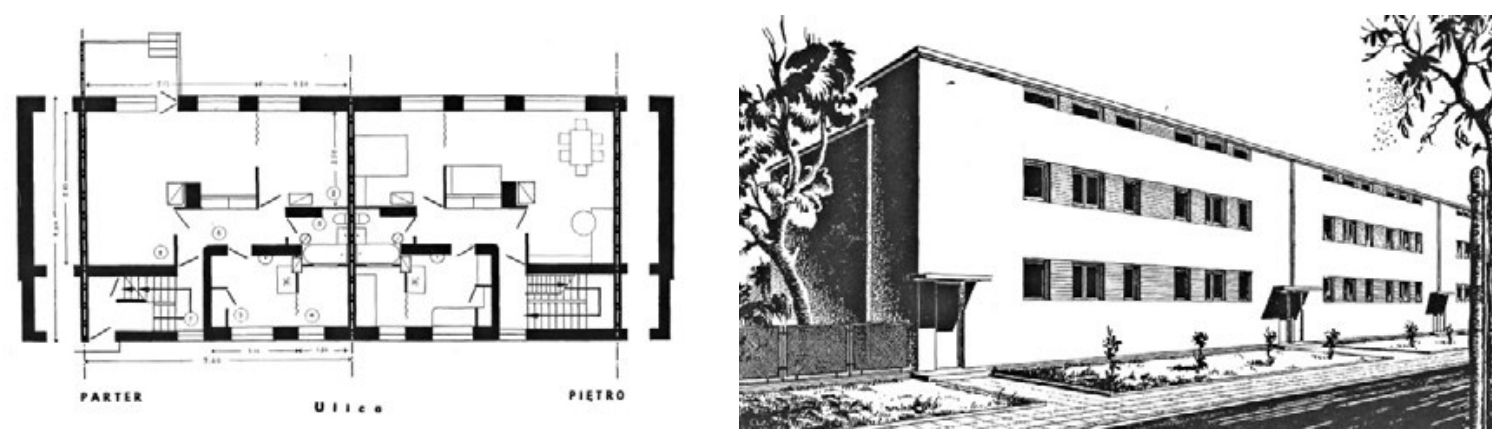

Fig. 14. Terrace unit, type 407, proj. J. Kieszkowski, Source: The Catalog of typical... 1934 (reprint)

\section{Four-family residential development - quadruple buildings}

This type of buildings is associated with twin housing development. Four apartments are located at the corners, with independent entrances and gardens. Typically, such objects are constructed as single-storey buildings with a roof void or attic. This type of a house was widely used four on-site workers' housing estates (as patronage housing) e.g. at the Krupp steelworks in Essen in the Ruhr area, in Germany, as steelworks masters' dwellings (Meisterhäuser). 


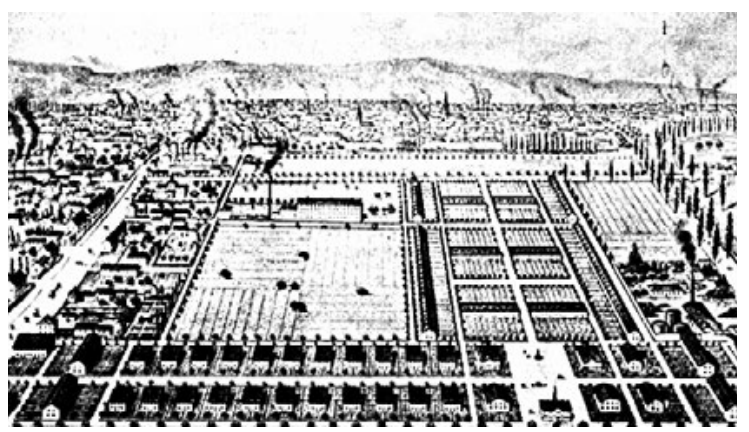

Fig. 15. Mulhouse estate plan; Source: http://www.rheinischeindustriekultur.de..., access: 15.07.2017

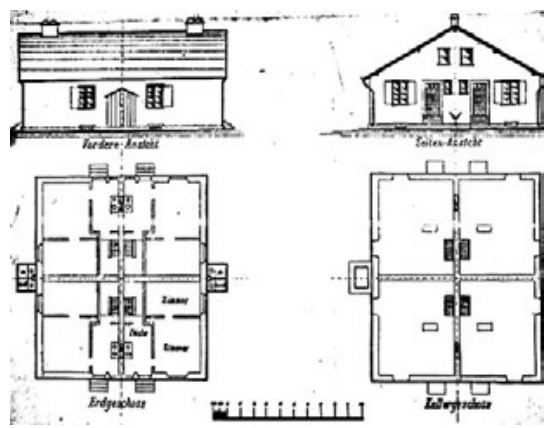

Fig. 16. Four-family building, Mulhouse; Source: http://www. rheinische-industriekultur.de... , access: 15.07.2017

An example of on-site workers' housing with four-dwelling units is the town of Mulhouse (Mulomousienne des Cités Ouvrieres (SOMCO), France). It followed the design of an engineer Émile Muller in the north / northwestern part of the town. The settlement was established on June 10,1853, and the whole complex was erected in stages through 1897 [http://www.crdp-strasbourg..., access: 15.07.2017]. The city was built on a grid of perpendicular streets and passages. The plots were square or rectangular in shape depending on the type of buildings to be erected (Fig. 15).

There are three types of residential buildings within the estate. Most frequent among them is a four-family building where each of the three-room flats is located at the corner, has a habitable loft space, a separate entrance and a garden surrounding it (Fig. 16).

Another example can be found in the abovementioned Chemin Vert garden in Reims, France. The four-family building consists of three-room, two-storey, side-by-side flats with a kitchen. (Fig. 17.).
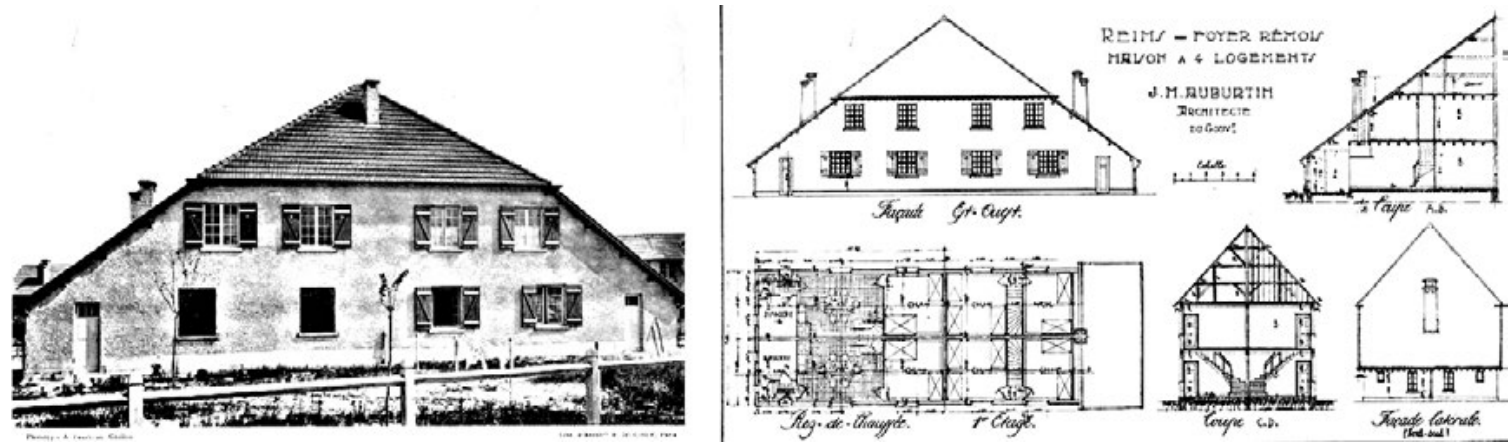

Fig. 17. Twin four-family building, Chemin Vert; Source: http://www.cite-jardin-reims.culture.fr..., access: 20.07.2017

A four-family building is also characteristic of manor farm complexes. First farm living quarter designs appeared in the late eighteenth and early nineteenth centuries. Four independent units were situated in a rectangular or square shaped building, each consisting of a chamber larder and hallway. The second variant was joining each pair of residential units, consisting of a chamber and a larder, by a common hallway [Rozbicka 2007]. The four-dwelling units, in the described or modified form, were designed and erected until the beginning of the 20th century (Fig. 19). 


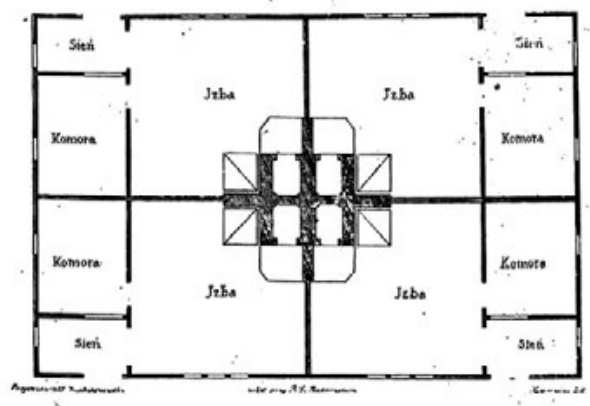

Fig. 18. Four-dwelling unit interior plan, Source: Zabierzowski 1856 (reprint), Tab.XXII

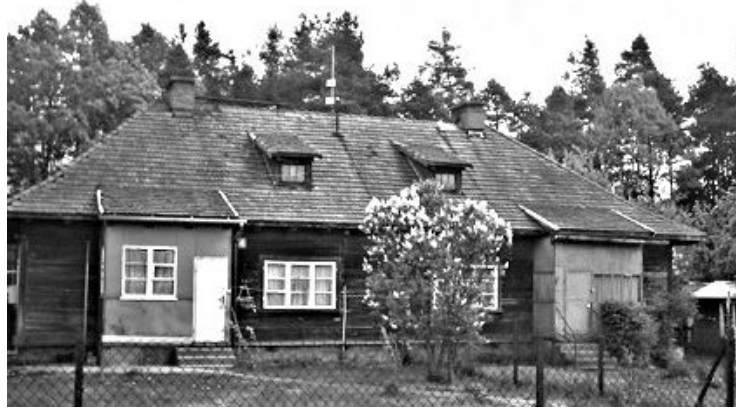

Fig. 19. Hajnówka, Four-dwelling house from 1930s; Source: https://pl.wikipedia.org/wiki..., access: 02.03.2016

In 1939, Frank Floyd Wright built the Suntop four-family residential complex in Ardmore, Pennsylvania [Giedion 1968]. In the design of the building, Wright used a "windmill" plan in which the apartments were separated by brick walls intersecting at right angles. In the ill-lit middle part of the building there are ventilation, sewerage, electrical and heating ducts (Fig. 20).
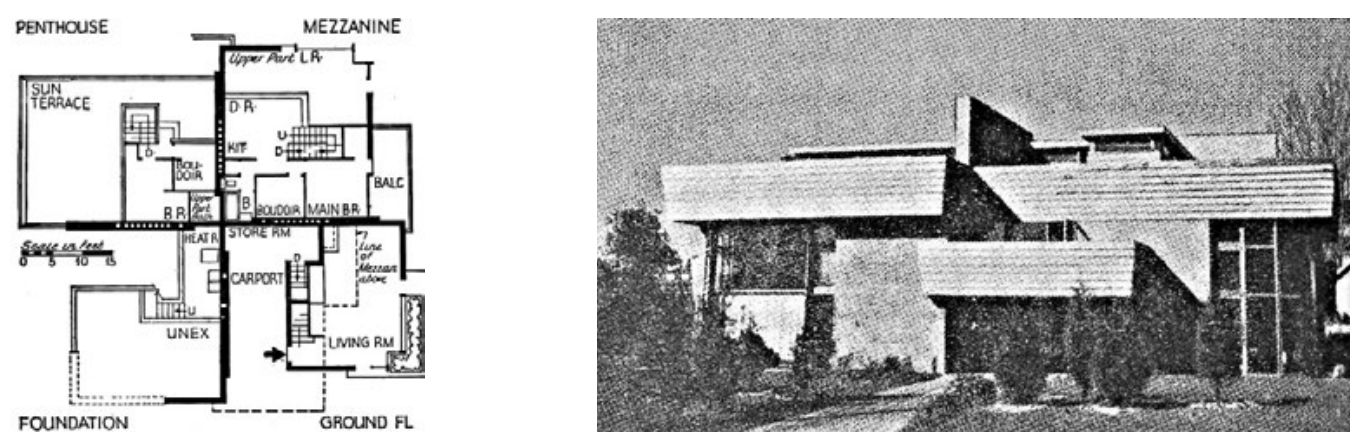

Fig. 20. Four-family residential complex Suntop, Ardmore, Pensylwania (1939); Source: Giedion 1968, p. 438

\section{Back-to-back buildings (blind-backs)}

This type of development, least frequently described in written works, is characteristic for its segments with two two-storey, lit from one side flats, arranged in a mirror image. The residential units have separate entrances and gardens located alongside. The described layout is an intensification of the four-family housing, achieved through duplication and collocation of several such objects. Such houses were cheap in construction and did not require a large plot.

The concept appeared in the previously described Mulhouse (Mulhousienne Société des Cités Ouvrieres (SOMCO)).

Back-to-back housing is also found in the aforementioned maqnor farm housing. For example, in a handbook "A brief outline of rural construction" by Kazimierz Obrębowicz, published in 1886, a situation plan of a back- to back two-bay terrace house shows entrances located in both front walls [Rozbicka 2007]. As a result, constructions erected were suitable for six or eight families -4 or 8-dwelling housing units (Fig. 21, Fig. 22). 


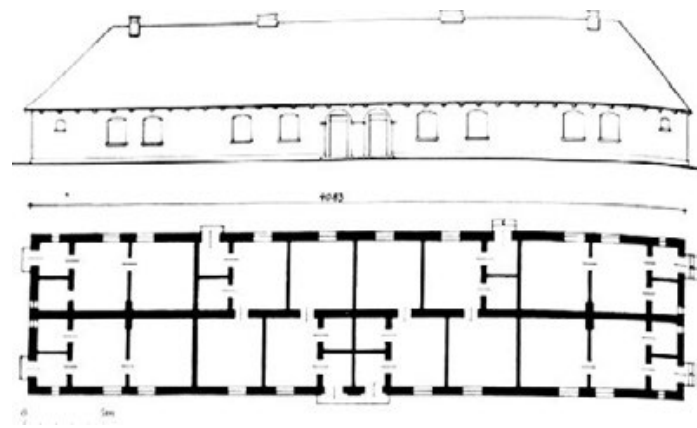

Fig. 21. Eight-family farm workers' housing Pałuki (1926); Source: Rozbicka 2007, p. 166

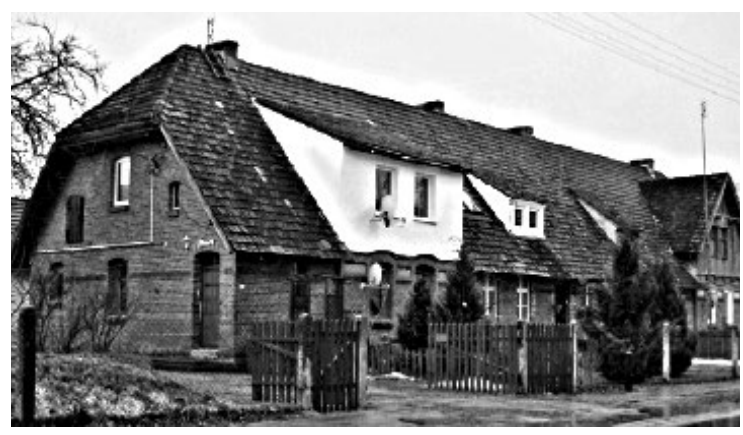

Fig. 22. Six-family farm workers's housing, Krąg; Source: Witek 2010, p. 326

\section{Conclusions}

Low-rise intensive housing was originally created to provide dwellings for the poor, industrial and farm workers and individual users. Its character and form allowed for the erection of buildings that meet the minimum hygienic and health requirements of the living environment. The main reason for using this type of residential development was the economy. Low-rise intensive housing was cheaper and required smaller plots than freestanding or compact but one-flat constructions. The same factor also plays a key role nowadays. Today's low-rise intensive residential development uses the types of buildings described in the paper, two of which are the most popular: over-and-under and back-to-back flat type buildings. The buyer acquires a substitute of single-family house, often with a garden, at the price of a flat in multi-family housing.

\section{References}

[1] A collective work edited by Chmielewskiego J.M., 1996: Low-rise intensive housing, University of Warsaw Publishing House, Warsaw

[2] Giedion S., 1968: Space, time and architecture. The birth of a new tradition. (in Polish), PWN, Warsaw

[3] Koch W., 1996: Styles in architecture (in Polish), Świat Książki Publishing House, Warsaw

[4] Krassowski W., 2007 , Problems of Polish architecture. Schemes of plans for residential buildings (in Polish), Warsaw University of Technology Publishing House, Warsaw

[5] Kwiatkowski B., 2012: Manor farms in Lublin Region. History of development and housing. (in Polish), Lublin University of Technology, Lublin

[6] Lamparska M., 2017: Patronage housing estates in space of European civilization. Cultural heritage of workers and their everyday culture (in Polish), Acta Geographica Silesiana, 11/2 (26), Sosnowiec, p. 51-61

[7] Rozbicka M., 2007: A Small Home with a Garden in the Background: The Theory and Practice of Popular Residential Architecture in Interwar Poland. (in Polish), Warsaw University of Technology Publishing House, Warsaw

[8] The Catalog of typical houses for small residential development (in Polish), 1934, National Capital Fund 1934; reprint, "Górnoleśne" Publishing House, Lublin 2007

[9] Tłoczek I., 1985: Housing in the Polish countrywide (in Polish), PWN, Warsaw

[10] Witek M., Waldemar W., 2010: Manor farm complexes in the cultural landscape of Polanów Community (in Polish), chapter in the collective work edited by Rączkowski W., Sroka J., History and Culture of the Sławno region, Vol. X: Town and Polanów Community., Fund. „Dziedzictwo”, Sławno - Polanów, p. 305-331

[11] Zabierzowski A., 1856, Practical rural construction (in Polish), Government town printing house of Radom County, Radom (reprint)

[12] Zadworny M., 2013: The concept of cheap social housing for the poorest families facing their needs today in Poland (in Polish), Wrocław University of Science and Technology Publishing House, Wroclaw 
[13] Załęcka-Myszkiewicz M., 2014: Social architecture. Single-family housing, chapter in the collective work: Habitats - Social Architecture, Wrocław University of Science and Technology Publishing House, Wrocław, p. 251-261

\title{
Websites
}

[1] http://snailinthecity.blogspot.nl/2013/04/factory-housing-mulhouse-style.html access: 15.07.2017

[2] https://greatacre.wordpress.com/2011/10/ access: 02.03.2016

[3] http://www.cite-jardin-reims.culture.fr/ access: 20.07.2017

[4] https://en.wikipedia.org/wiki/Brumleby z dn. 13.09.2017 access: 25.07.2017

[5] https://web.archive.org/web/20110719124441/http://www.dac.dk/visKanonVaerk.asp?artikellD=2564 access: 13.09 .2017

[6] https://da.wikipedia.org/wiki/Kartoffelr\%C3\%A6kkerne access:14.09.2017

[7] http://www.crdp-strasbourg.fr/data/patrimoine-industriel/mulhouse-19/cite_ouvriere.php?parent=25 access:15.07.2017

[8] http://www.architectuurgids.nl/project/list_projects_of_architect/arc_id/10/prj_id/732 z dn. 10.10.2017. access: 10.10.2017

\section{Full links to graphics and figures}

Fig. 4. http://www.fotocommunity.de /pc/pc/cat/805/display/30784368, acess: 02.03 .2016

Fig. 5. https://www.flickr.com/photos /bradfordlibraries/8429156237, acess: 02.03.2016

Fig. 6. https://greatacre.wordpress.com/2011/10/, acess: 02.03.2016

Fig. 7. http://www.cite-jardin-reims.culture.fr/2_chantier_chemin_vert/4_logements.html, access: 20.07.2017

Fig. 8. http://kunstbib.dk/samlinger/arkitekturtegninger/vaerker/000010369/3, access:13.09.2017

Fig. 9. https://upload.wikimedia.org/wikipedia/commons/1/12/Brumleby_02.JPG, access:.13.09.2017

Fig. 10. http://1.bp.blogspot.com/ XKNxrmlg5po/UgfaxtdjXLI/AAAAAAAATR0/ 1D9hGMckzrw /s1600/main+street.jpg, access: 14.09 .2017

Fig. 11. http://kunstbib.dk/samlinger/arkitekturtegninger/vaerker/000056054/3, access:14.09.2017

Fig. 12. http://davidhannafordmitchell.tumblr.com/post/97468015288/j-j-p-oud-arbeiterwohnungen-hoek-van-holland, access: 10.10 .2017

Fig. 13. https://i.pinimg.com/originals/af/28/c3/af28c31287f4f77d7c9ece46cec4e6d1.jpg, access: 10.10 .2017

Fig. 15. http://www.rheinische- industriekultur.de/objekte/Essen/siedlEssen/siedIEssen.html, access: 15.07.2017

Fig. 16. http://www.rheinische-industriekultur.de/objekte/Essen/siedlEssen/siedlEssen.html, access: 15.07.2017

Fig. 17. http://www.cite-jardin-reims.culture.fr/2_chantier_chemin_vert/4_logements.html, access: 20.07.2017

Fig. 19. https://pl.wikipedia.org/wiki /Osiedle_Miko\%C5\%82aja_Reja_\%28Hajn\%C3\% B3wka\%29, access: 02.03 .2016

\section{Niska, intensywna zabudowa mieszkaniowa. Geneza i kształtowanie się modelu zamieszkiwania}

\begin{abstract}
Streszczenie: Artykuł koncentruje się na poszukiwaniu, stanowiących pierwowzór, historycznych przykładów niskiej, intensywnej zabudowy mieszkaniowej. Pod względem formy taka zabudowa przypomina współczesne realizacje mieszkaniowe wznoszone w zespołach zabudowy jednorodzinnej zwartej, które charakteryzują się występowaniem dwóch mieszkań w jednym segmencie mieszkalnym. Tak wybudowane lokale mieszkalne mają wielkość trzypokojowego, mieszkania w zabudowie wielorodzinnej a realizowane są w oparciu o przepisy dotyczące zabudowy jednorodzinnej.
\end{abstract}

Słowa kluczowe: zabudowa mieszkaniowa, niska, intensywna, zabudowa zwarta 